\title{
Pengembangan Sistem Informasi Pengembangan Sistem Informasi Berbasis Web untuk Peningkatan Kinerja Unit Bursa Kerja Khusus SMK Negeri 1 Tanjung Raya
}

\author{
Amalina $^{1 *}$, Yuliani Dewi Putri ${ }^{2}$ \\ Program Studi Sistem Informasi \\ STMIK Indonesia \\ Padang \\ *amalina@stmikindonesia.ac.id
}

\begin{abstract}
Abstrak-SMK Negeri 1 Tanjung Raya merupakan salah satu satuan pendidikan yang berada di Kabupaten Agam. SMK Negeri 1 Tanjung Raya memiliki sebuah unit Bursa Kerja Khusus (BKK) yang bertugas memberikan informasi kepada siswa praktik kerja industri (prakerin) mengenai tempat magang yang dapat mereka pilih. Unit BKK juga berfungsi untuk memberikan informasi kepada alumni terkait lowongan pekerjaan. Informasi yang diberikan kepada siswa dan alumni dilakukan menggunakan papan pengumuman di sekolah. Cara tersebut dirasa kurang efektif karena informasi tidak cepat sampai kepada siswa dan lulusan yang membutuhkan. Siswa dan alumni harus sering datang ke sekolah agar mendapat informasi yang mutakhir sedangkan sebagian siswa dan alumni tinggal jauh dari sekolah dalam kondisi transportasi yang kurang baik. Untuk mengatasi permasalahan tersebut, dikembangkan sistem informasi berbasis web untuk pengelolaan data di unit BKK. Sistem informasi dirancang menggunakan bahasa pemrograman PHP dan basis data MySQL. Sistem melibatkan lima user yakni admin, operator BKK, operator prakerin, siswa dan alumni. Kelima level user yang terdaftar memiliki akun private untuk dapat masuk ke dalam sistem yakni username dan password dengan enkripsi MD5. Halaman utama sistem menampilkan informasi berita, lowongan kerja, dan rekapitulasi data alumni. Sistem diharapkan dapat meningkatkan kinerja unit BKK dalam memberikan informasi tentang lowongan kerja kepada siswa prakerin dan alumni.
\end{abstract}

Kata kunci: Sistem Informasi, Bursa Kerja Khusus, Pemograman Web.

\section{Pendahuluan}

Teknologi informasi diterapkan di berbagai bidang kehidupan seperti di bidang ekonomi [1,2], sosial [3], budaya [4], dan di dunia pendidikan [5]. Pada bidang pendidikan, sistem informasi diterapkan baik untuk manajemen sekolah [6][7] maupun untuk proses pembelajaran [8]. Pemanfaatan teknologi informasi secara optimal dapat memberi dampak positif yang mendukung perkembangan dunia pendidikan. Teknologi informasi yang akurat dan mudah diakses bermanfaat untuk meningkatkan kinerja kegiatan akademik yang berlangsung pada sebuah satuan pendidikan.

Sekolah Menegah Kejuruan (SMK) Negeri 1 Tanjung Raya merupakan salah satu satuan pendidikan yang berada di Kabupaten Agam. Sekolah ini merupakan sarana pendidikan formal yang membekali peserta didik dengan ilmu pengetahuan, keterampilan dan kemampuan sosialisasi di masyarakat. Hal ini tidak terlepas dari misi SMK pada umumnya yang mempersiapkan anak didiknya untuk siap kerja dan menempatkan para lulusannya ke dunia kerja. Ciri khas SMK adalah kegiatan praktik kerja industri (prakerin) bagi siswanya untuk memperkenalkan siswa ke dunia kerja yang segera dihadapi. Oleh sebab itu, setiap SMK memiliki badan khusus untuk menangani prakerin dan penempatan kerja lulusan. Badan ini adalah Bursa Kerja Khusus (BKK).

BKK adalah sebuah lembaga yang dibentuk di SMK Negeri dan Swasta sebagai unit pelaksana yang memberikan pelayanan dan informasi lowongan kerja serta merupakan mitra Dinas Tenaga Kerja dan Transmigrasi. SMK sebagai subsistem pendidikan nasional yang bertangung jawab dalam penyiapan SDM tingkat menengah yang andal dan berorientasi kepada kebutuhan pasar, harus mampu mengembangkan inovasi untuk mempengaruhi perubahan kebutuhan pasar sehingga dapat mewujudkan kepuasan pencari kerja. BKK SMK merupakan salah satu komponen penting dalam mengukur keberhasilan pendidikan SMK karena BKK menjadi lembaga yang berperan mengoptimalkan penyaluran tamatan SMK dan sumber informasi untuk pencari kerja.

BKK SMK Negeri 1 Tanjung Raya menangani pekerjaannya secara manual. Penyampaian informasi lowongan kerja pihak BKK dilakukan dengan menempelkan brosur pada papan pengumuman yang ada di sekolah atau menyampaikan secara langsung kepada siswa untuk disampaikan kepada alumni yang dikenal. Sementara itu, untuk pengumpulan data alumni 
yang bekerja atau yang melanjutkan ke perguruan tinggi dilakukan ketika ada alumni yang berkunjung ke sekolah. Cara manual ini memiliki masalah sulitnya pencarian data lulusan dan terbatasnya penyebaran informasi lowongan kerja kepada lulusan.

Untuk meningkatkan kinerja pada unit BKK, baik dalam pengolahan, penyimpanan dan pencarian data atau pun penyaluran lulusan SMK Negeri 1 Tanjung Raya, maka dibangun sebuah sistem informasi berbasis web menggunakan bahasa pemograman PHP dan MySQL. Tulisan ini membahas pengembangan sistem informasi untuk unit BKK. Adapun sistematika penulisan pada paper ini adalah sebagai berikut. Pada bagian kedua dijelaskan metode penelitian. Bagian ketiga menyajikan hasil penelitian, dan bagian keempat menyajikan diskusi. Kemudian, bagian kelima merupakan kesimpulan.

\section{Metode}

Metode penelitian yang digunakan dalam penelitian ini adalah metode pengembangan sistem. Salah satu fasilitas internet yang sangat populer adalah world wide web yang merupakan sebuah jaringan global situs internet multimedia. Pengembangan situs web telah dilakukan dengan cepat dalam beberapa tahun terakhir untuk rentang tujuan yang luas di berbagai domain seperti pendidikan, pemerintahan, museum, bisnis, hiburan, dan kesehatan [9]. Saat ini, ribuan perusahaan di dunia menggunakan web untuk media promosi dan menawarkan produknya dalam bentuk informasi bersifat on-line di internet. Aplikasi web membantu dalam banyak kegiatan kehidupan sehari-hari, seperti belanja, membaca berita, interaksi sosial, perbankan di rumah, perencanaan perjalanan atau meminta janji dokter [10].

Metode pengembangan sistem merupakan tahapan-tahapan yang dikerjakan oleh analisis sistem dan programmer dalam membangun sistem informasi. Metode ini lebih dikenal dengan Sistem Development Life Cycle (SDLC). Adapun tahapan-tahapan metode SDLC adalah:

\subsection{Perencanaan Sistem (System Planning)}

Perencanaan sistem merupakan menentukan tujuan dan sasaran yang ingin dicapai sehingga dapat membenahi sistem ke arah yang lebih baik. Perencanaan sistem yang dilakukan dalam penelitian ini salah satunya menentukan output yang akan dihasilkan dari sistem informasi unit bursa kerja khusus SMK Negeri 1 Tanjung Raya.

\subsection{Analisis Sistem (System Analysis)}

Analisis sistem merupakan gambaran keadaan sistem yang sesungguhnya kemudian melakukan perbaikan untuk mengatasi masalah yang terjadi di dalam sistem.

Analisis terhadap sistem yang sedang berjalan adalah mempelajari sistem yang digunakan saat ini pada Bursa Kerja Khusus yang ada di SMK Negeri 1 Tanjung Raya yang kemudian dianalisis untuk mengetahui perincian sistem secara lebih detail. Setelah dilakukan penelitian, diperoleh gambaran singkat tentang keadaan sistem dan beberapa kelemahan yang ada. Bentuk aliran sistemnya dapat dijelaskan sebagai berikut: a. Alumni yang bekerja dan melanjutkan studi melapor ke sekolah.

b. Operator BKK melakukan pencatatan data secara manual kemudian diarsipkan.

c. Perusahaan memberikan informasi lowongan kerja.

d Operator BKK mengandakan informasi lowongan pekerjaan lalu menempelkan di mading dan disampaikan kepada siswa yang mengetahui di mana alumni berada, lalu siswa menyampaikan informasi lowongan pekerjaan kepada alumni yang di kenal.

e. Siswa prakerin melengkapi data prakerin untuk melakukan vertifikasi kepada kepala jurusan prakerin.

f. Kepala jurusan prakerin melakukan verifikasi data siswa prakerin, jika nilai siswa bermasalah maka kepala jurusan prakerin memberikan informasi nilai yang bermasalah untuk diperbaiki, bagi nilai siswa yang tidak bermasalah kepala jurusan prakerin memberikan blanko data pribadi dan surat izin orang tua untuk di isi lalu diarsip oleh Operator BKK.

Adapun bentuk aliran sistem yang digunakan oleh unit BKK SMK Negeri 1 Tanjung Raya dapat digambarkan dalam bentuk activity diagram pada Gambar 1.

Melihat cara kerja sistem saat ini pada SMK Negeri 1 Tanjung Raya, terdapat beberapa kelemahan dan kekurangan serta kendala-kendala yang sering ditemui. Maka perlu diajukan sebuah sistem informasi yang dapat memperbaiki sistem informasi unit bursa kerja khusus SMK Negeri 1 Tanjung Raya.

Adapun bentuk aliran sistem informasi BKK SMK N 1 Tanjung Raya yang baru ini melakukan perubahan dalam penyampaian adanya lowongan kerja dengan merancang suatu database. Untuk lebih jelasnya, dapat dilihat dalam bentuk activity diagram adalah sebagai berikut:

a. Input data alumni yang bekerja, calon tenaga kerja, dan melanjutkan studi.

b. Operator BKK merekap data alumni yang bekerja, calon tenaga kerja, dan melanjutkan studi.

c. Perusahaan memberikan informasi lowongan kerja.

d. Operator BKK mengecek kuota lalu mengunggah file lowongan kerja.

e. Alumni menelusuri informasi lowongan kerja dan mengirim berkas lamaran kerja yang sesuai dengan persyaratan.

f. Perusahaan menerima berkas lamaran kerja dan mengecek lamaran tersebut apakah memenuhi syarat atau tidak, jika syarat terpenuhi maka alumni bekerja tapi jika berkas lamaran tidak menuhi syarat maka perusahaan memberikan informasi kekurangan syarat.

g. Siswa melihat daftar usulan perusahaan yang menerima siswa prakerin, lalu siswa input data siswa dan tempat prakerin.

h. Kepala jurusan prakerin memvalidasi data siswa dan tempat prakerin, merekap data siswa prakerin dan perusahaan yang telah divalidasi, dan memberikan ke Operator BKK.

Adapun bentuk aliran sistem informasi yang dibuat dalam penelitian ini dapat digambarkan dalam bentuk activity diagram seperti terlihat pada Gambar 2 . 


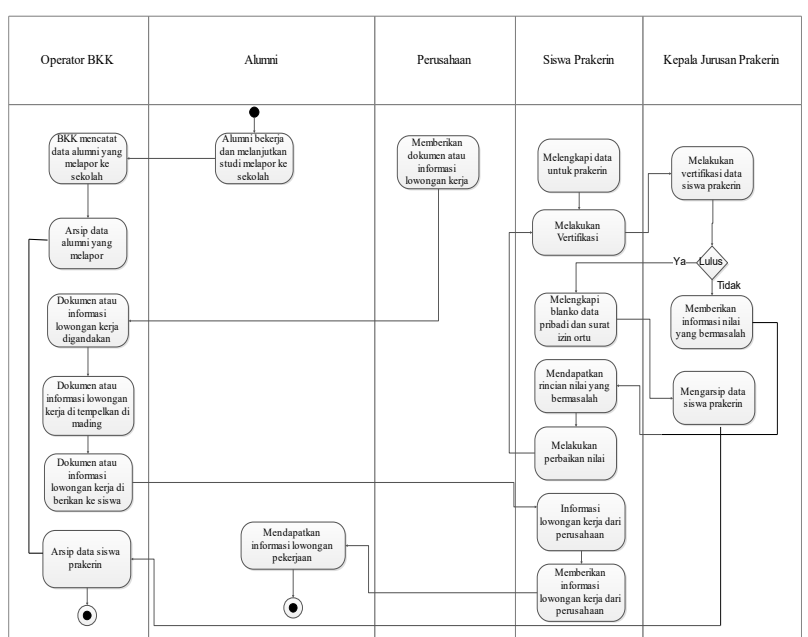

Gambar 1. Activity diagram aliran sistem saat ini

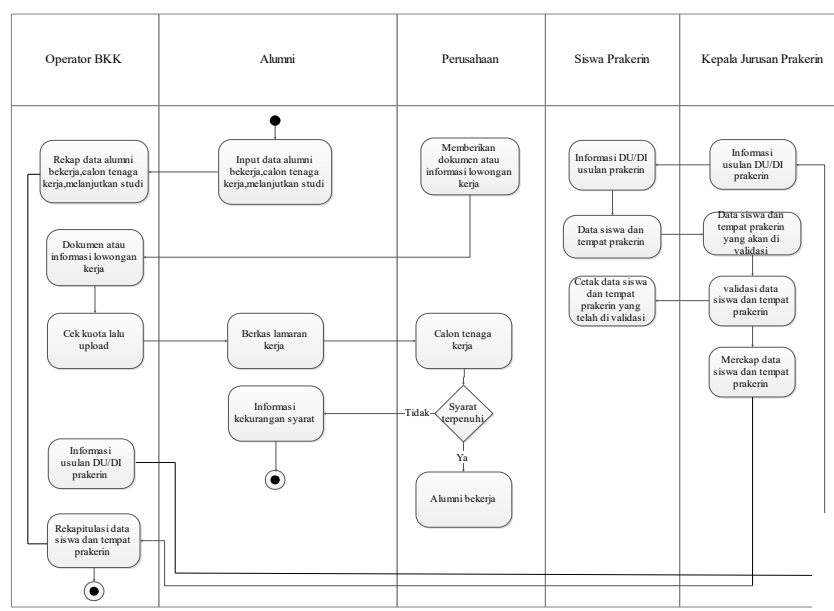

Gambar 2. Activity diagram aliran sistem

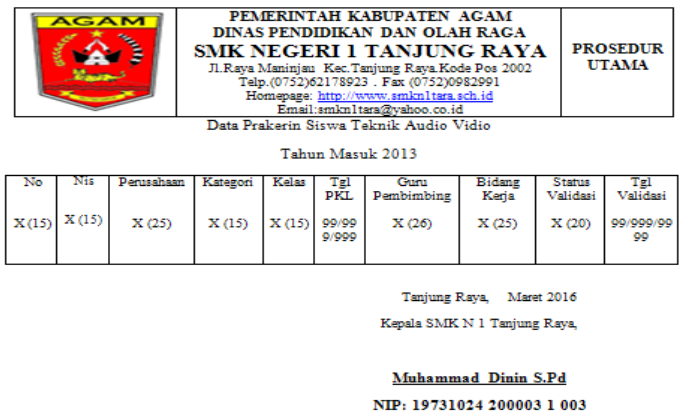

Gambar 3. Desain laporan data siswa prakerin

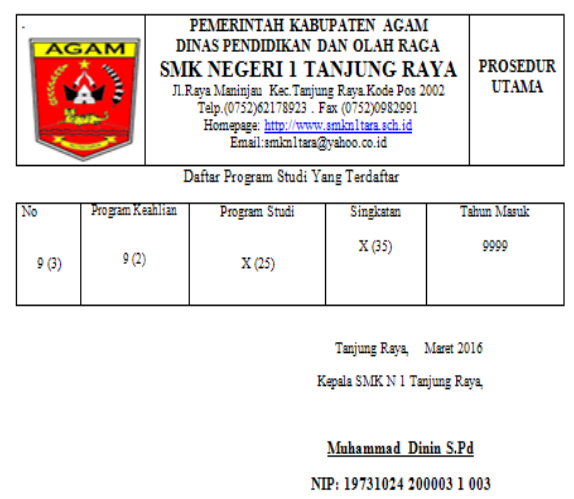

Gambar 4. Desain laporan data alumni pertahun

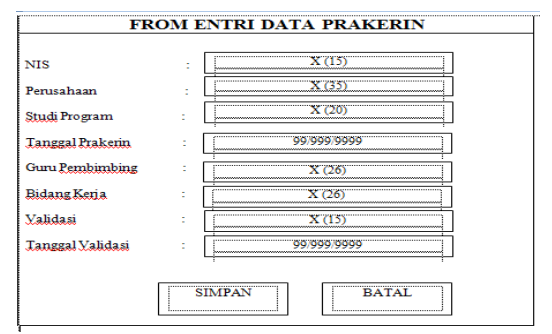

Gambar 5. Entri data prakerin siswa sistem informasi BKK

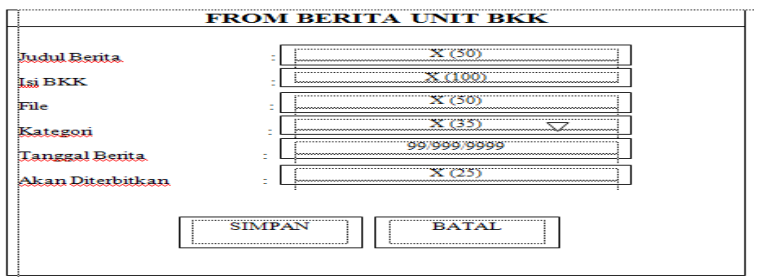

Gambar 6. Desain form data berita sistem informasi BKK SMK Negeri 1 Tanjung Raya

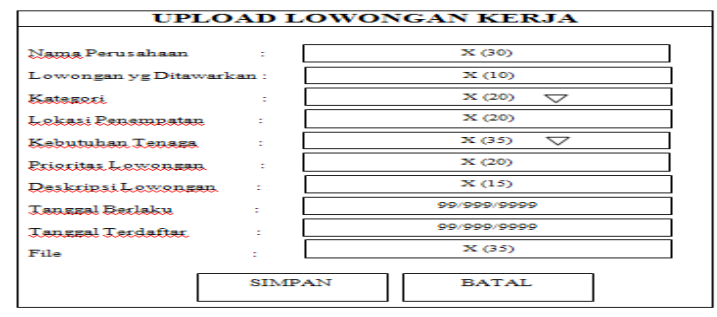

Gambar 7. Desain form upload lowongan kerja BKK SMK Negeri 1 Tanjung Raya

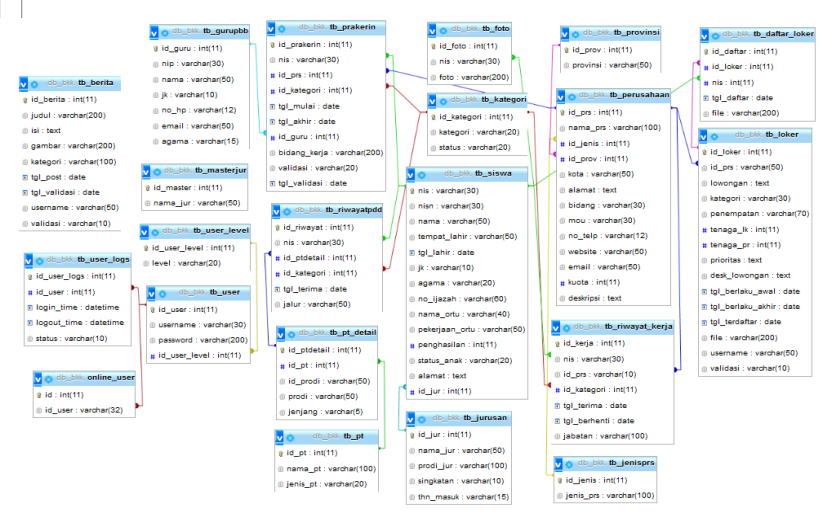

Gambar 8. Relasi antartabel

\subsection{Perancangan Sistem (Design System)}

Perancangan sistem menggambarkan proses secara urut. Hasil rancangan dituangkan dalam bentuk aplikasi yang dijadikan acuan atau pedoman untuk menghasilkan suatu keputusan atau tindakan. Perancangan dilakukan mengunakan alat bantu perancangan sistem seperti UML dan ERD.

Penelitian ini menggunakan hardware dengan spesifikasi: Processor Pentium IV, RAM 512 MB, Monitor, keyboard, mouse, Hard Disk dengan kapasitas 250 MB, Printer, CD/DVD RW. Sedangkan perangkat lunak yang digunakan adalah: Sistem Operasi Windows 7, Xampp win32-1.7.7, Firefox Setup 24.0. Adapun desain input, output, dan relasi antar-file dapat dilihat seperti berikut ini: a. Desain Output

Tujuan utama dari desain output adalah menghasilkan suatu bentuk yang efektif, mudah dipahami, cepat, 
dan tepat waktu, dengan kata lain hasil keluaran yang dihasilkan haruslah memudahkan bagi setiap unsur yang terlihat atau yang mengunakan. Adapun desain output yang dirancang adalah sebagai berikut:

a) Laporan Data Siswa Prakerin dapat dilihat pada Gambar 3.

b) Laporan Data Alumni Per Tahun dapat dilihat pada Gambar 4.

b. Desain Input

Desain input merupakan tahap menguraikan jumlah data yang dibutuhkan untuk membangun laporan yang disajikan aplikasi. Desain input dapat berupa pembuatan form entry, form proses dan form lainnya yang dibutuhkan untuk menghasilkan informasi. Form entry yang dibuat berupa entry data user, data prakerin siswa, entry data perusahaan dan entry data pembimbing. Salah satu bentuk desain entry data adalah sebagai berikut.

a) Entri Data Prakerin Siswa dapat dilihat pada Gambar 5.

c. Desain Proses

Desain proses merupakan tahap pengelolaan bursa kerja khusus SMK Negeri 1 Tanjung Raya. Berikut desain prosesnya:

a) Form Data Berita BKK SMK Negeri 1 Tanjung Raya dapat dilihat pada Gmabar 6.

b) Form Upload Lowongan Kerja dapat dilihat pada Gambar 7.

d. Desain Relasi Antartabel

Desain relasi antartabel sistem informasi unit bursa kerja khusus dapat dilihat pada Gambar 8.

Gambar relasi antartabel di atas mendeskripsikan aliran data pada database yang akan digunakan. Sistem informasi BKK SMK Negeri 1 Tanjung Raya ini akan melibatkan beberapa tabel yang saling berelasi. Seperti tb_ siswa akan berelasi dengan tb_prakerin, tb_riwayatpdd, tb_ riwayat_kerja, tb_jurusan, tb_daftar_loker, tb_gurupbb, dan tb_foto. Sedangkan tb_perusahaan akan berelasi dengan tb_jenisprs, tb_loker, tb_daftar_loker, tb_prakerin, tb_riwayat_kerja. Tabel tb_pt berelasi dengan tb_pt_detail yang menampung informasi Perguruan Tinggi akan berelasi dengan tb_riwayatpdd.

\subsection{Implementasi Sistem (System Imple- mentation).}

Implementasi sistem yaitu menjalankan dan menggunakan aplikasi dengan imput data, proses pengolahan data, dan penyampaian informasi kepada user sesuai dengan tujuan sistem. Pada tahapan tersebut, sistem informasi unit bursa kerja khusus SMK Negeri 1 Tanjung Raya yang dibangun akan diterapkan langsung di lapangan dengan memberikan pelatihan kepada penguna.

\section{Hasil}

Adapun hasil pembuatan sistem informasi berbasis web pada unit BKK SMK Negeri 1 Tanjung Raya adalah:

\subsection{Menu Utama}

\section{a. Menu Halaman Utama}

Halaman utama adalah fitur akses antara user dengan aplikasi yang hanya dapat mengakses dan menggunakan fitur umum berdasarkan kategori. Halaman utama antarmuka aplikasi ini dikelola dengan beberapa modul yang dinamakan admin, operator $\mathrm{BKK}$, alumni, operator prakerin, dan siswa prakerin, sehingga informasi-informasi dapat ditampilkan, disimpan, dan dihapus.

\section{b. Halaman Menu Utama Admin}

Halaman menu utama admin berfungsi untuk memanagement user, menambah user, dan melihat user, mulai dari entry user, ubah user, dan cetak laporan. Halaman admin hanya bisa diakses oleh user admin. Tampilan halaman admin dapat dilihat pada Gambar 10.

\section{c. Halaman Menu Utama Operator BKK}

Halaman menu utama operator BKK terdiri dari beberapa menu yaitu menu perusahaan, jurusan, perguruan tinggi, lowongan kerja, calon tenaga kerja, berita $\mathrm{BKK}$, rekapitulasi alumni, rekapitulasi siswa prakerin dan laporan. Dari menu laporan terdapat 5 submenu yaitu laporan perusahaan, laporan jurusan, laporan perguruan tinggi, laporan alumni, dan laporan siswa prakerin. Halaman ini bisa diakses hanya operator BKK sendiri, karena bisa dibilang operator BKK ini merupakan induk dari sistem ini. Tampilan halaman utama operator BKK dapat dilihat pada Gambar 11.

\section{d. Halaman Menu Utama Siswa Prakerin}

Halaman menu utama siswa prakerin terdiri dari beberapa menu yaitu menu home, tambah data prakerin, dan lihat data prakerin. Dari menu laporan terdapat submenu yaitu laporan data prakerin. Halaman siswa prakerin mengisi data dan tempat di mana siswa prakerin dan menunggu operator prakerin untuk menvalidasi data siswa prakerin. Tampilan halaman menu utama siswa prakerin dapat dilihat pada Gambar 12.

\section{e. Halaman Menu Utama Alumni}

Halaman menu utama alumni terdiri dari beberapa menu yaitu data pribadi, riwayat kerja, dan riwayat pendidikan. Di mana alumni mengisi data pribadinya, jurusan, dan tahun masuk. Alumni mencari lowongan kerja, memenuhi persyaratan dan mengirimkan berkas lamaran kepada perusahaan, alumni juga bisa mengupload berita di sistem informasi unit bursa kerja khusus SMK Negeri 1 Tanjung Raya. Tampilan menu utama alumni dapat dilihat pada Gambar 13.

\subsection{Menu Proses}

\section{a. Entry Data Unit BKK}

Entry data Unit BKK merupakan form untuk mengisi data berita yang ada di SMK Negeri 1 Tanjung Raya. Pada form ini terdapat tombol simpan untuk menyimpan data ke dalam database. Untuk lebih jelasnya dapat dilihat pada Gambar 14.

\section{b. Upload Lowongan Kerja}

Form upload lowongan kerja merupakan proses untuk menyimpan file lowongan kerja ke server. Pada form ini terdapat tombol simpan untuk mengupload file ke server. Untuk lebih jelasnya dapat dilihat pada Gambar 15. 


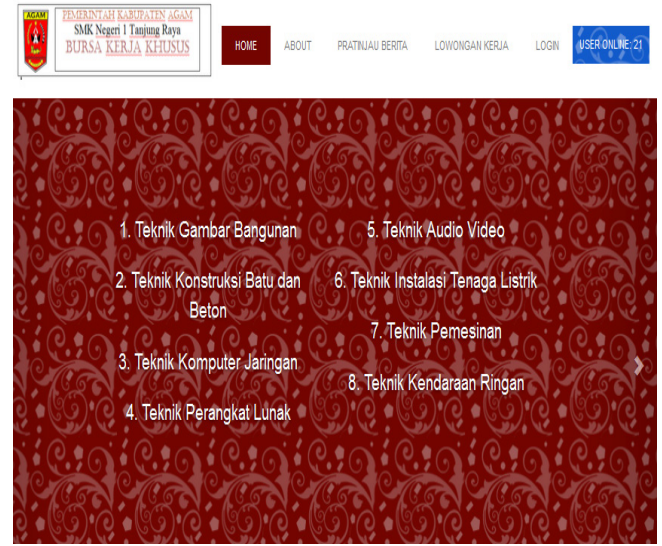

Gambar 9. Halaman utama BKK SMK Negeri 1 Tanjung Raya
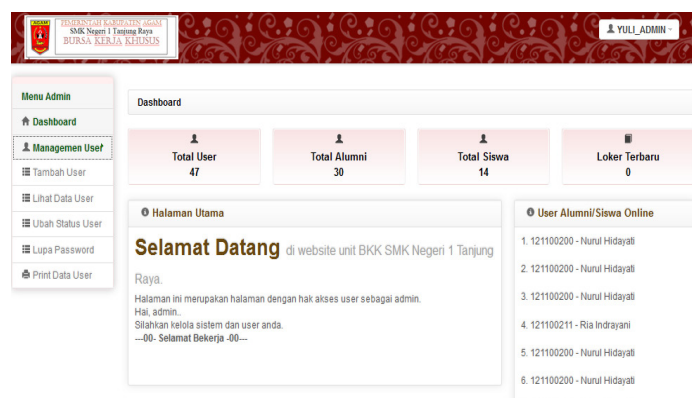

Gambar 10. Halaman menu utama admin
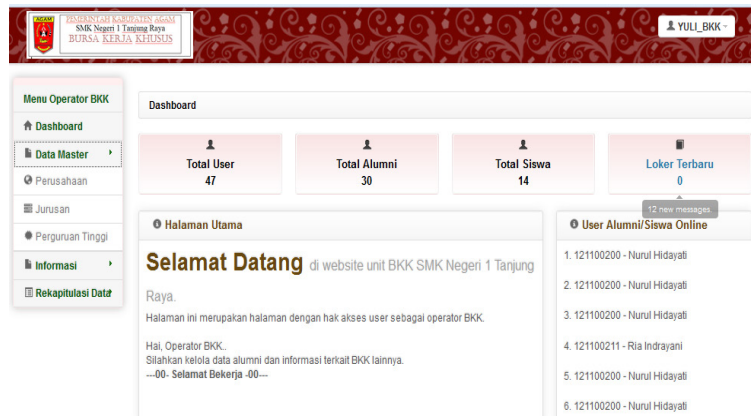

Gambar 11. Halaman utama operator BKK
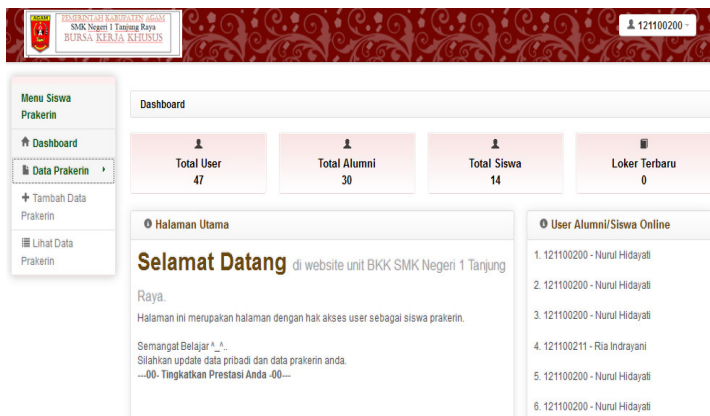

Gambar 12. Halaman menu utama siswa prakerin

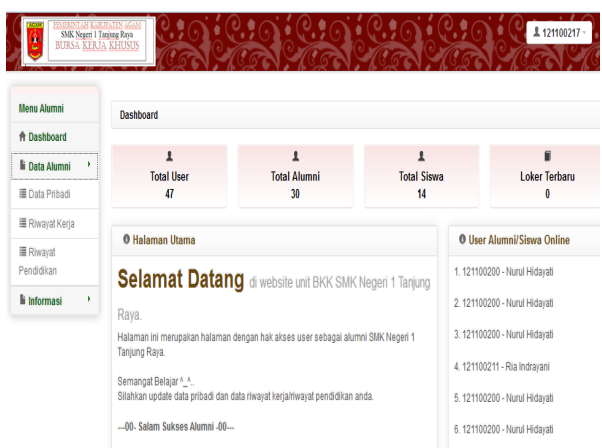

Gambar 13. Halaman menu utama alumni

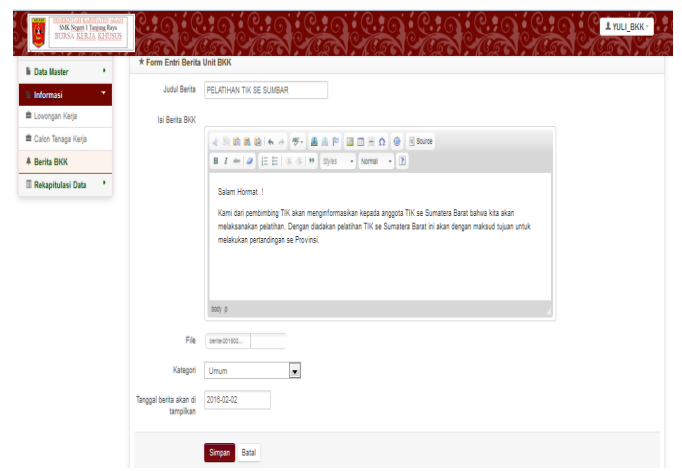

Gambar 14. Entry data berita unit BKK SMK Negeri 1 Tanjung Raya

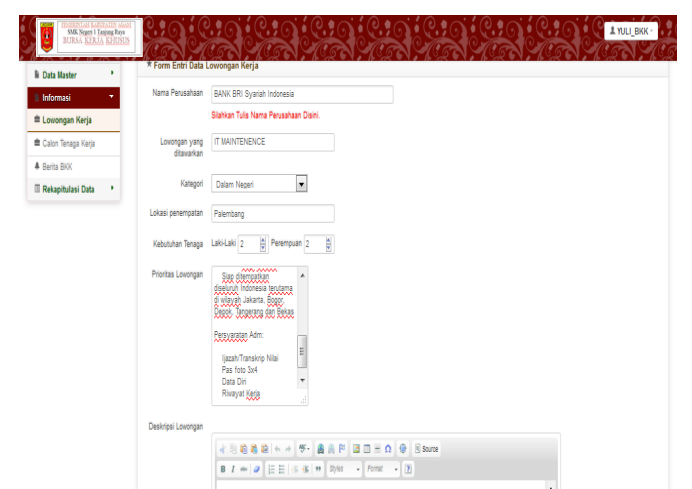

Gambar 15. Form upload lowongan kerja BKK SMK Negeri 1 Tanjung Raya

\subsection{Menu Laporan}

Menu laporan merupakan menu untuk melihat data hasil akhir yang dikeluarkan oleh sistem informasi unit BKK SMK Negeri 1 Tanjung Raya. Adapun laporanlaporan yang dihasilkan dalam sistem ini adalah sebagai berikut:

\section{a. Laporan Data Siswa Prakerin}

Laporan data siswa prakerin SMK Negeri 1 Tanjung Raya dapat dilihat pada Gambar 16.

\section{b. Laporan Data Alumni}

Laporan data alumni SMK Negeri 1 Tanjung Raya dapat dilihat pada Gambar 17. 


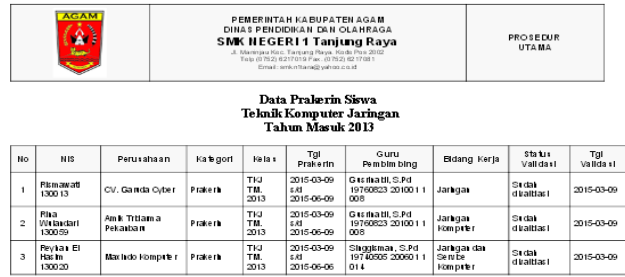

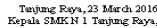

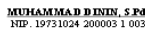

Gambar 16. Laporan Data Siswa Prakerin

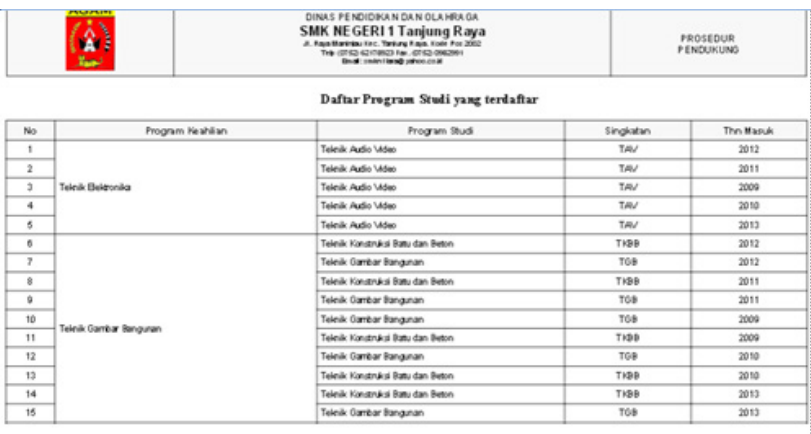

Tampurs Raya, 22 March 2016 KopulasmK. 11 Tangung Raya

Gambar 17. Laporan Data Alumni

MUHAMMAD DININ, SPd

Tabel 1. Perbandingan sistem yang lama dan sistem yang dibuat dalam penelitian ini

\begin{tabular}{|c|c|c|}
\hline No & Analisis sistem lama & $\begin{array}{c}\text { Analisis sistem yang } \\
\text { dibuat }\end{array}$ \\
\hline 1. & $\begin{array}{l}\text { Pengolahan data alumni } \\
\text { diproses mengunakan aplikasi } \\
\text { microsoft excel. }\end{array}$ & $\begin{array}{lr}\text { Pengolahan data } & \text { alumni } \\
\text { menggunakan } & \text { aplikasi } \\
\text { sistem informasi } & \text { berbasis } \\
\text { web. } & \end{array}$ \\
\hline 2. & $\begin{array}{l}\text { Pencarian data alumni } \\
\text { dilakukan dengan membolak- } \\
\text { balikan file dokumen atau sheet } \\
\text { pada aplikasi Microsoft Excel }\end{array}$ & $\begin{array}{l}\text { Data bisa diinputkan ke } \\
\text { dalam sistem untuk mencari } \\
\text { nama alumni. }\end{array}$ \\
\hline 3. & $\begin{array}{l}\text { Pekerjaan tata usaha dalam } \\
\text { mengarsipkan data alumni } \\
\text { membutuhkan waktu lama. }\end{array}$ & $\begin{array}{l}\text { Pekerjaan dilakukan lebih } \\
\text { efektif dan efisien }\end{array}$ \\
\hline 4. & \begin{tabular}{llr} 
Memberikan & \multicolumn{2}{c}{ informasi } \\
lowongan kerja harus \\
dipasang di mading dan \\
disampaikan ke siswa yang \\
mengetahui & \multicolumn{2}{c}{ keberadaan } \\
alumni. & \multicolumn{2}{c}{}
\end{tabular} & $\begin{array}{l}\text { Informasi lowongan kerja } \\
\text { mudah diakses alumni } \\
\text { dalam satu aplikasi. }\end{array}$ \\
\hline 5. & $\begin{array}{l}\text { Siswa harus mencari informasi } \\
\text { adanya perusahaan menerima } \\
\text { siswa prakerin. }\end{array}$ & $\begin{array}{l}\text { Siswa cukup melihat } \\
\text { di aplikasi di mana saja } \\
\text { perusahaan yang menerima } \\
\text { siswa prakerin. }\end{array}$ \\
\hline
\end{tabular}

\section{Diskusi}

Pengembangan sistem informasi untuk unit Bursa Kerja Khusus memberikan beberapa keuntungan sebagai berikut. a. Sistem informasi BKK SMK Negeri 1 Tanjung Raya dapat menggunakan sistem yang telah terintegrasi dengan program aplikasi dan menggunakan database, yaitu program sistem informasi BKK SMK Negeri 1 Tanjung Raya berbasis web dengan menggunakan bahasa pemograman PHP \& MySQL.

b. Pengolahan data lebih akurat, efektif, dan efisien.

c. Mempermudah operator BKK dalam menyampaikan informasi lowongan kerja kepada alumni yang belum mendapatkan pekerjaan.

d. Menghemat penggunaan kertas.

e. Mempermudah alumni untuk mencari informasi lowongan pekerjaan.

f. Laporan yang dihasilkan akan lebih efektif.

Rancangan sistem baru ini merupakan pengembangan dari sistem lama, tujuannya untuk meningkatkan efesiensi dan efektivitas kerja dalam pengolahan data alumni dan didukung oleh aplikasi bahasa pemograman PHP MySQL yang merupakan DBMS (database management system) yang didistribusikan secara gratis dibawah lisensi dari General Public Licensi (GPL), di mana setiap orang bebas untuk menggunakannya tetapi tidak boleh untuk dijadikan program induk turunan bersifat close source (komersial) [11]. Jadi aplikasi memiliki database yang dapat berfungsi sebagai penyimpanan data yang telah diarsipkan sebelumnya dan dapat digunakan oleh operator BKK untuk menyampaikan adanya lowongan kerja kepada alumni yang belum bekerja. Adapun perbedaan sistem yang lama dengan sistem informasi yang dibuat dalam penelitian ini dapat dilihat pada Tabel 1.

Berdasarkan Tabel 1, terlihat bahwa dengan adanya sistem informasi berbasis web, kinerja pada unit BKK, baik dalam pengolahan, penyimpanan, dan pencarian data atau pun penyaluran lulusan SMK Negeri 1 Tanjung Raya lebih efektif dan efisien.

\section{Kesimpulan}

Berdasarkan hasil dan pembahasan, dapat diambil kesimpulan sebagai berikut.

a. Sistem informasi unit BKK SMK Negeri 1 Tanjung Raya yang dibangun berbasis web dapat diakses secara online melalui jaringan internet oleh alumni yang akan menelusuri daftar lowongan kerja.

b. Aplikasi yang dibangun menyediakan menu-menu program antarmuka untuk memudahkan operator BKK dalam menyampaikan informasi lowongan kerja dan membuat laporan yang dibutuhkan.

c. Sistem yang dibangun menerapkan proteksi keamanan (security) dasar pada komputer, aplikasi, dan server.

d Kinerja pada unit BKK, baik dalam pengolahan, penyimpanan dan pencarian data atau pun penyaluran lulusan SMK Negeri 1 Tanjung Raya berjalan lebih efektif dengan adanya sistem informasi berbasis web.

\section{Persantunan}

Ucapan terima kasih kepada STMIK Indonesia Padang yang membiayai penelitian ini dengan nomor kontrak: 895.016/A.12/STMIK-I/2016. 


\section{Daftar Pustaka}

[1] R. Herlambang, A. Makmum, B. Brylian, A. K. A. Gumawang, and H. Thamrin, "Aplikasi Sparta (Sistem Perencanaan Untuk Usaha Kecil Menengah)," Khazanah Informatika: Jurnal Ilmu Komputer dan Informatika, vol. 2, no. 1, pp. 26-34., 2016.

[2] H. A. Mumtahana, S. Nita, and A. W. Tito, "Pemanfaatan Web E-Commerce untuk Meningkatkan Strategi Pemasaran," Khazanah Informatika: Jurnal Ilmu Komputer dan Informatika, vol. 3, no. 1, pp. 6-15, 2017.

[3] D. Pratama, D.A. Hakim, Y. Prasetya, N. R. Febriandika, M. Trijati and U. Fadlilah, "Rancang Bangun Alat dan Aplikasi untuk Para Penyandang Tunanetra Berbasis Smartphone Android," Khazanah Informatika: Jurnal Ilmu Komputer dan Informatika, vol. 2, no. 1, pp. 14-19, 2016.

[4] E. Sudarmilah, "Augmented Reality Edugame Senjata Tradisional Indonesia," Khazanah Informatika: Jurnal Ilmu Komputer dan Informatika, vol. 1, no. 1, pp. 12-15, 2015.

[5] A. Ristyabudi, and H. Thamrin, "Penerapan Single Page Application pada Proses Pengisian Online Data Rencana Studi Mahasiswa," Khazanah Informatika: Jurnal Ilmu Komputer dan Informatika, vol. 2, no. 1, pp. 1-9, 2016.
[6] A. Visscher, P. Wild, D. Smith and L. Newton, "Evaluation of the implementation, use and effects of a computerised management information system in English secondary schools," British Journal of Education Technology, vol. 34, no. 3, pp. 357-366, 2003.

[7] C. P. Nolan and D. A. Ayres, "Developing a "good" information system for schools: The new Zealand experience," International Journal of Educational Research, vol. 25, no. 4, pp. 307-321, 1996.

[8] Y. Zahide, C. M. Reigeluth, S. Kwon, Y. Kageto and Z. Shao, "A comparison of learning management systems in a school district: Searching for the ideal personalized integrated educational system (PIES)," Interactive Learning Environment, vol. 22, no. 6, pp. 721-736, 2014.

[9] K. Devi and A. Sharma, "Framework for Evaluation of Academic Website," International Journal of Computer Techniques, vol. 3, no. 2, pp. 234-239, 2016.

[10] J. Grigera, A. Garrido, J. M. Rivero and G. Rossi, "Automatic detection of usability smells in web applications," International Journal of Human-Computer Studies, vol. 97, pp. 129-148, 2017.

[11] S. Deni, Sistem Inventory mini market dengan php dan jquery, Yogyakarta: Lokomedia, 2012. 